\title{
ANALISIS PENDAPATAN USAHATANI DAN EFISIENSI KELEMBAGAAN PERTANIAN PADI ORGANIK DAN ANORGANIK DI DESA LIMBANGAN KECAMATAN SUKARAJA KABUPATEN SUKABUMI
}

\author{
M Apriani ${ }^{1 a}$, W Nahraeni ${ }^{1}$, A Yoesdiarti $^{1}$ \\ ${ }^{1}$ Jurusan Agribisnis, Fakultas Pertanian, Universitas Djuanda Bogor \\ Jalan Tol Ciawi 1, Kotak Pos 35 Bogor 16720 \\ ${ }^{a}$ Korespondensi: Mira Apriani, E-mail : mirakaisarapriani6@gmail.com
}

\begin{abstract}
ABSTRAK
Padi organik menghasilkan beras yang memiliki keunggulan dibandingkan dengan beras dari padi anorganik. Keunggulan beras organik antara lain: relatif aman untuk dikonsumsi karena tidak mengandung residu kimia, teksturnya lebih pulen, dan masa simpannya lebih lama, sehingga permintaan dan harga beras organik meningkat. Penelitian ini bertujuan untuk mengetahui pendapatan usahatani padi organik dan anorganik, persepsi anggota terhadap kelompok tani dan menghitung biaya transaksi. Pengumpulan data dilaksanakan pada bulan Juni 2019 di Desa Limbangan Kecamatan Sukaraja Kabupaten Sukabumi. Jumlah petani sampel sebanyak 20 orang petani padi organik (Kelompok Tani Ciloa) dan 30 orang petani padi anorganik (Kelompok Tani Subur Tani) yang dipilih secara acak sederhana. Metode analisis yang digunakan adalah analisis pendapatan, R/C, uji beda, skala Likert dan analisis biaya transaksi untuk mengukur efisiensi kelembagaan. Hasil penelitian menunjukkan bahwa pendapatan padi organik lebih tinggi dari pendapatan padi anorganik dengan perbandingan $\mathrm{R} / \mathrm{C}$ sebesar 1,48 dan 1,13. Persepsi petani baik padi organik maupun anorganik terhadap peran kelembagaan kelompok tani dinilai sudah baik terutama dalam hal menyelesaikan konflik, interaksi antar anggota kelompok tani dan bebas mengeluarkan pendapat. Namun dipersepsikan kelompok belum dapat berperan untuk dapat meningkatkan pendapatan setiap musim, dan akses informasi masih lemah. Rasio biaya transaksi terhadap penerimaan Kelompok Tani Ciloa dan Subur Tani sebesar 0,23 dan 0,51. Hal ini menunjukkan bahwa kelembagaan Kelompok Tani Ciloa (untuk padi organic) relatif lebih efisien. Perlu peningkatan peran kelompok dalam hal akses terhadap informasi dan pasar, dan mengurangi biaya transaksi untuk meningkatkan efisiensi kelembagaan kelompok tani.
\end{abstract}

Kata kunci : R/C, Skala Likert, Biaya Transaksi, Efisiensi Kelembagaan 


\section{PENDAHULUAN}

Komoditas tanaman pangan yang penting dan berperan dalam pembangunan sektor pertanian adalah komoditas padi. Padi merupakan salah satu komoditas utama yang ditanam petani Indonesia yang menghasilkan beras sebagai makanan pokok penduduk Indonesia. Produksi padi di Indonesia mencapai jumlah 79.171.916 ton pada tahun 2016. Angka tersebut didapat dari beberapa sentra produksi di Indonesia, seperti Jawa Timur, Jawa Barat, Jawa Tengah, Sulawesi Selatan, Sumatera Utara, Sumatera Selatan, Lampung, Sumatera Barat, NTB dan Kalimantan Selatan (Pusdatin, 2016).

Di Indonesia, Provinsi Jawa Barat menempati urutan ke dua sebagai sentra produksi padi, dengan jumlah . sebesar 12.090.951 ton tahun 2018 dengan produktivitas 5,98 ton/ha (BPS, 2018). Pada tahun 2014 - 2018, terjadi kenaikan produksi padi yang disesabkan oleh adanya kenaikan luas panen padi.

Kabupaten Sukabumi merupakan salah satu lumbung padi di Jawa Barat Budidaya padi dilakukan dengan dua cara, yaitu padi organik dan anorganik. Menurut Badan Standardisasi Nasiona (BSN) 2015, usahatani padi organik merupakan usahatani padi yang tidak menggunakan zat kimia dalam kegiatan budidayanya mulai dari pengolahan tanah, pemupukan, dan pemberantasan hama penyakit tanaman. Usahatani padi anorganik merupakan usahatani padi yang masih menggunakan bahan kimia dalam proses kegiatan usahatani pada pemupukan dan pemberantasan hama penyakit tanaman

Kabupaten Sukabumi mempunyai beberapa kecamatan dan desa yang sebagian petaninya sudah menerapkan budidaya padi organik secara berkelanjutan dan sebagian besar masih berusahatani padi anorganik, diantaranya Desa Limbangan Kecamatan Sukaraja (Dinas Pertanian Kabupaten Sukabumi, 2019). Menurut data dari Balai Penyuluhan Pertanian (BPP) Kecamatan
Sukaraja, di Desa Limbangan terdapat kelompok tani yang petaninya menerapkan usahatani padi organik dan anorganik. Petani yag menerapkan usahatani padi organik terhimpun di Kelompok Tani Ciloa sedangkan kelompok tani yang masih menerapkan usahatani padi anorganik yakni Kelompok Tani Subur Tani.

Kelompok Tani Ciloa Desa Limbangan Kecamatan Sukaraja menerapkan pertanian padi organik secara swadaya. Pada awal penerapan, produksi usahatani padi organik menurun sampai beberapa tahun, biaya produksi yang dikeluarkan juga jumlahnya besar karena memerlukan banyak pupuk organik untuk menetralkan tanah dari ketergantungan pupuk kimia. Dengan menurunnya produksi di awal penerapan serta tingginya biaya produksi, hal ini akan berdampak pada penurunan pendapatan petani padi organik ${ }^{1)}$.

Kelompok Tani Subur Tani merupakan kelompok tani di Desa Limbangan yang anggotanya menanam padi anorganik. Budidaya padi ini menggunakan bahan kimia dengan harapan produksinya tinggi sehingga pendapatan yang diterima petani juga tinggi

Kelembagaan merupakan basis terbentuknya modal sosial yang dapat menfasilitasi kerjasama dalam aktivitas agribisnis padi organik (Nuraini dkk 2016). Dalam pengembangan padi organic, diperlukan dukungan yang kuat untuk mengantisipasi permasalahan yang sering ditemukan antara lain harga dan pemasaran. Hal ini akan dapat dicapai apabila petani mampu berhimpun dalam suatu kekuatan bersama, seperti halnya kelompok tani. Namun, permasalahannya adalah masih relatif lemahnya patisipasi petani (Aminah 2018). Persepsi petani terhadap kelompok tani dapat dilihat dari peran kelompok dalam membantu memecahkan masalah usahatani yang dialami anggota, kemudahan akses informasi, pasar, teknologi dan 
permodalan (Astuti 2017). Di sisi lain peran kelembagaan padi organic maupun anorganik masih lemah. Hal ini disebabkan masih tidak efisiennya kelembagaan dilihat dari tingginya biaya transaksi yang dikeluarkan.

Dari uraian di atas, penelitian ini penting dilakukan untuk mengkaji pendapatan padi organik dan padi anorganik di Desa Limbangan Kecamatan Sukaraja Kabupaten Sukabumi, sebagai bahan informasi sistem usahatani manakah yang menghasilkan pendapatan usahatani lebih menguntungkan. Selain itu dilihat dari kelembagaan pertaniannya, perlu dikaji mengenai persepsi anggota terhadap peran kelompok tani serta analisis baiaya transaksi kelompok tani organik dan anorganik untuk melihat apakah kelembagaannya sudah efisien atau tidak. Oleh karena itu beberpa rumusan permasalahan yang akan dikaji dalam penelitian ini, yaitu 1) Apakah terjadi perbedaan pendapatan usahatani padi organik dengan padi anorganik di Desa Limbangan Kecamatan Sukaraja Kabupaten Sukabumi, 2) Bagaimana persepsi petani tentang peran kelompok tani dan 3) Berapa besar biaya transaksi kelompok tani padi organik dengan anorganik.

Penelitian ini bertujuan untuk 1) Menganalisis dan membandingkan pendapatan petani usahatani padi organik dan anorganik di Desa Limbangan Kecamatan Sukaraja Kabupaten Sukabumi. 2) Mengidentifikasi persepsi petani terhadap peran kelompok tani dan 3) Menghitung biaya transaksi kelompok tani padi organik dan anorganik

\section{BAHAN DAN METODE}

\section{Lokasi dan Waktu Penelitian}

Penelitian ini dilaksanakan di Kelompok Tani Ciloa dan Kelompok Tani Subur Tani Desa Limbangan Kecamatan Sukaraja Kabupaten Sukabumi. Pemilihan lokasi penelitian dilaksanakan secara sengaja (purposive) dengan pertimbangan bahwa Kelompok Tani Ciloa merupakan satu-satunya kelompok tani yang menerapkan usahatani padi organik dan Subur Tani merupakan kelompok tani yang menerapkan usahatani padi anorganik. Pengempulan data dilakukan pada bulan Juni 2019.

\section{Metode Pengumpulan Data /Jenis dan Sumber Data}

Data yang digunakan dalam penelitian ini terdiri atas data primer dan data sekunder. Data primer diperoleh melalui observasi lapang dan wawancara secara langsung dengan petani menggunakan kuesioner. Data sekunder diperoleh dari jurnal ilmiah, buku-buku. Badan Pusat Statistik, Kementerian Pertanian, Dinas Pertanian, Balai Penyuluhan Pertanian (BPP), internet, berbagai literatur dan sumber lain yang mendukung penelitian ini.

\section{Metode Pengambilan Sampel}

Petani sampel padi organic berjumlah 20 orang yang diambil secara sensus di Kelompok Tani Ciloa, sedangkan petani sampel padi anorganik berjumlah 30 orang yang diambil menggunakan metode simple random sampling di. Kelompok ani Subur Tani.

\section{Metode Pengolahan dan Analisis Data \\ Data yang dikumpulkan dalam} penelitian ini dianalisis secara kualitatif dan kuantitatif. Analisis kualitatif diolah dan diuraikan secara deskriptif, untuk mengetahui karakteristik pertanian organik dan anorganik dan peran kelompok tani. Analisis kuantitatif dilakukan untuk mengetahui pendapatan petani dan biaya transaksi. Pengolahan data dilakukan dengan menggunakan program Microsoft Excel.

\section{Analisis Pendapatan Usahatani}

Secara umum teori pendapatan usahatani dikemukakan oleh Shinta 2011; Soekartawi 2006; dan Suratiyah 2009. Untuk menjawab tujuan pertama 
dilakukan analisis pendapatan usahatani padi organik dan anorganik. Pendapatan didapat dari selisih antara penerimaan total dengan biaya total. Untuk penerimaan total usahatani padi organik dirumuskan sebagai berikut :

$$
\begin{aligned}
& \mathrm{TR}_{1}=\mathrm{Y}_{1} \cdot \mathrm{Py}_{1} \\
& \mathrm{TR}_{2}=\mathrm{Y}_{2} \cdot \mathrm{Py}_{2}
\end{aligned}
$$

Dengan:

$\mathrm{TR}_{1} \quad=$ penerimaan padi organik $(\mathrm{Rp})$ $\mathrm{TR}_{2}=$ penerimaan padi anorganik $(\mathrm{Rp})$ $\mathrm{Y}_{1}$ dan $\mathrm{Y}_{2}=$ produksi padi organic dan anorganik $(\mathrm{Kg})$

$\mathrm{Py}_{1}$ dan $\mathrm{Py}_{2}=$ harga padi organic dan anorganik (Rp)

Biaya total (TC) untuk usahatani padi organik dan anorganik dirumuskan sebagai berikut :

$$
\begin{aligned}
& \mathrm{TC}_{1}=\mathrm{TFC}_{1}+\mathrm{TVC}_{1} \\
& \mathrm{TC}_{2}=\mathrm{TFC}_{2}+\mathrm{TVC}_{2}
\end{aligned}
$$

Dengan:

$\mathrm{TC}_{1}$ dan $\mathrm{TC}_{2} \quad=$ Biaya Total padi organic dan anorganik (Rp)

$\mathrm{TFC}_{1}$ dan $\mathrm{TFC}_{2}=$ Biaya tetap total usahatani padi organic dan anorganik meliputi biaya sewa lahan, penyusutan alat dan pajak (Rp)

$\mathrm{TVC}_{1}=$ Biaya variabel total usahatani padi organik meliputi biaya penggunaan benih, pupuk kandang, pupuk organik (pupuk organik cair/kompos/bokashi), tenaga kerja dan pestisida alami (Rp)

$\mathrm{TVC}_{2}=$ Biaya variabel total usahatani padi anorganik meliputi biaya penggunaan benih, pupuk kandang, pupuk kimia (urea, SP36, $\mathrm{KCl}, \mathrm{NPK})$ ), tenaga kerja dan pestisida kimia. (Rp)

Untuk menghitung pendapatan usahatani padi organik dapat diperoleh dengan rumus sebagai berikut :

$$
\begin{array}{ll}
\pi_{1} & =\mathrm{TR}_{1}-\mathrm{TC}_{1} \\
\pi_{2} & =\mathrm{TR}_{2}-\mathrm{TC}_{2}
\end{array}
$$

dengan:

$\pi_{1}$ dan $\pi_{2}=$ pendapatan usahatani padi organik dan anorganik (Rp)

\section{Analisis R/C}

Untuk mengetahui kelayakan usahatani pada penelitian ini digunakan analisis R/C baik untuk padi organik maupun anorganik. Rumus yang digunakan adalah:

$$
\begin{aligned}
& \mathrm{R} / \mathrm{C}_{1}=\frac{T R_{1}}{T C_{1}} \\
& \mathrm{R} / \mathrm{C}_{2}=\frac{T R_{2}}{T C_{2}}
\end{aligned}
$$

Dengan:

$\mathrm{R} / \mathrm{C}_{1}=$ rasio imbangan penerimaan dengan biaya untuk padi organik

$\mathrm{R} / \mathrm{C}_{2}=$ rasio imbangan penerimaan dengan biaya untuk padi anorganik

\section{Persepsi Petani terhadap Peran Kelompok Tani Padi Organik dan Anorganik}

Untuk menjawab tujuan 2, digunakan skala Likert dengan skala 1 sampai 5.

Skor 1 : sangat tidak setuju,

Skor 2 : tidak setuju,

Skor 3 : kurang setuju,

Skor 4 : setuju, dan

Skor 5 : sangat setuju.

Adapun pertanyaan untuk menganalisis persepsi petani diaptasi dari berbagai penelitian diantaranya Astuty 2017 dengan ditambahkan variabel yang relevan dengan kondisi lapangan

\section{Biaya Transaksi}

Untuk menjawab tujuan ke tiga dilakukan analisis biaya transaksi dalam kelembagaan kelompok tani yang di rumuskan sebagai berikut (Astuty 2017):

$\operatorname{TrC}=\Sigma \mathrm{Sij}$

dengan:

$\operatorname{TrC}=$ Total biaya transaksi dalam kelompok (Rp)

$\mathrm{Sij}=$ Komponen biaya transaksi dalam kelompok (Rp) 
Tingkat efisiensi usahatani dapat ditinjau dari rasio biaya transaksi terhadap penerimaan dengan rumus sebagai berikut:

$$
\operatorname{Rtr}=\frac{\operatorname{Tr} C}{R}
$$

dengan:

Rtr = Rasio biaya transaksi terhadap penerimaan

$\operatorname{TrC}=$ Total biaya transaksi dalam kelompok (Rp)

$\mathrm{R}=$ Total penerimaan dalam kelompok (Rp)

\section{HASIL DAN PEMBAHASAN}

\section{Karakteristik Petani Sampel}

Berdasarkan data hasil dari wawancara petani organik dan anorganik, karakteristik petani dapat dilihat pada Lampiran 1. Hasil penelitian menunjukkan bahwa umur petani padi organic sebagian besar $(45 \%)$ brada pada usia produktif (2435 tahun), sebaliknya petani anorganik berada pada umur tua (28-60 tahun) s3besar 47 persen. Pendidikan formal petani padi organic maupun anorganik hampir sama, sebagian besar $(50 \%$ dan $53 \%$ ) berpendidikan SD. Hal ini menunjukkan bahwa tingkat pendidikan petani masih rendah. Ini membuktikan bahwa untuk menjalankan kegiatan usahatani padi tidak melihat dari tingkatan pendidikan yang dimiliki oleh petani melainkan kemampuan petani untuk melaksanakan teknis budidaya secara benar, yang dapat dilihat dari pengalaman berusahatani juga hampir sama, $85-97 \%$ mempunyai pengalaman berusahatani di atas 10 tahun. Jumlah tanggungan keluarga baik petani organic maupun anorganik rata-rata berjumlah 3-5 orang.

Lahan yang dimiliki petani organic lebih kecil dibandingkan dengan lahan petani anorganik. Petani organic memiliki luas lahan $0-25 \mathrm{Ha}$, sedangakan luas lahan petani anorganik sebagian besar berada antara 0,15 - 0,5 Ha (67\%). Hal ini menunjukan bahwa padi organik masih dibudidayakan atau diusahakan di lahan yang relatif kecil. Petani di kedua kelompok tani berstatus sebagai petani penggarap $(>84 \%)$ dan hanya sebagian kecil sebagai pemilik penggarap. Hal ini menunjukan bahwa di Kelompok Tani Ciloa dan Subur Tani sebagian besar petani menyewa lahan sebagai penggarap. Usahatani padi di kedua kelompok merupakan pekerjaan utama.

\section{Analisis Pendapatan Usahatani}

Analisis pendapatan usahatani dihitung berdasarkan persamaan (1) sampai (6), dan $\mathrm{R} / \mathrm{C}$ rasio usahatani dihitung berdasarkan persamaan (7) dan (8). Analisis ini dilakukan untuk luas lahan 1 ha.

Tabel 1 Analisis Usahatani Padi Sawah Padi Organik dan Anorganik (Luas $1 \mathrm{Ha}$ ) di DesaLimbangan Kecamatan Sukaraja dalam Satu Periode Tanam, 2019

\begin{tabular}{llrr}
\hline No & \multicolumn{1}{c}{ Uraian } & Padi Organik & Padi Anorganik \\
\hline 1. & Jumlah Produksi Padi (Kg) & $6.873,00$ & $6.880,00$ \\
& Harga (Rp/kg) & $6.000,00$ & $4.200,00$ \\
& Penerimaan Total (Rp) & $41.235 .959,00$ & $28.895 .326,00$ \\
2. Biaya & & \\
Biaya Variabel & $121.644,00$ & $387.523,00$ \\
& & \\
a. Benih (Kg) & & \\
b. Pupuk (Kg) & $1.500 .000,00$ & \\
*Pupuk Kompos Padat (Kg) & $300.000,00$ & \\
*Pupuk Organik Cair (POC) (Ltr) & & \\
\hline
\end{tabular}




\begin{tabular}{|c|c|c|c|}
\hline No & Uraian & Padi Organik & Padi Anorganik \\
\hline & *Pupuk Urea (Kg) & & $403.029,00$ \\
\hline & *Pupuk SP $36(\mathrm{Kg})$ & & $249.649,00$ \\
\hline & *Pupuk NPK (Kg) & & $757.991,00$ \\
\hline & *Pupuk KCl (Kg) & & $382.000,00$ \\
\hline & * Pupuk Kandang (Kg) & & $263.889,00$ \\
\hline & *Pupuk NPK Mutiara (Kg) & & $590.000,00$ \\
\hline & c. Pestisida & & \\
\hline & *Paenibacillus polymyxa (Ltr) & $50.000,00$ & \\
\hline & *Pestisida Nabati (Ltr) & $50.990,00$ & \\
\hline & *Furadan $(\mathrm{Kg})$ & & $122.879,00$ \\
\hline & *Insektisida (Ltr) & & $198.600,00$ \\
\hline & *Fungisida (Kg) & & $155.556,00$ \\
\hline & d. Tenaga Kerja (HKSP) & $6.697 .989,00$ & $5.932 .589,00$ \\
\hline & *Borongan (Rp) & $3.436 .330,00$ & $3.439 .920,00$ \\
\hline & Biaya Variabel Total & $12.156 .953,00$ & $12.883 .625,00$ \\
\hline \multirow[t]{5}{*}{3.} & Biaya Tetap & & \\
\hline & a. Penyusutan Alat (Rp) & $352.851,00$ & $157.615,00$ \\
\hline & b. Sewa Lahan (Rp) & $15.196 .412,00$ & $12.460 .514,00$ \\
\hline & c. Pajak Lahan (Rp) & $236.330,00$ & $146.389,00$ \\
\hline & Biaya Tetap Total & $15.785 .593,00$ & $12.764 .518,00$ \\
\hline 4. & Jumlah Biaya Total & $27.942 .546,00$ & $25.648 .143,00$ \\
\hline 5. & Pendapatan & $13.293 .413,00$ & $3.247 .183,00$ \\
\hline 6. & $\mathrm{R} / \mathrm{C}$ & 1,48 & 1,13 \\
\hline
\end{tabular}

Berdasarkan data pada Tabel 1 terlihat bahwa meskipun produksi padi organic dan anorganik relatif hampr sama, namun karena harga gabah padi organik lebih tinggi, maka penerimaan total pun lebih tinggi. Biaya total untuk padi organic lebih tinggi dari padi anorganik (Rp27.942.546,00 vs Rp25648143,00). Pendapatan padi organik lebih tinggi, dapat dilihat pendapatan usahatani padi organik dan anorganik masing - masing adalah Rp. 13.293.413,-dan Rp. 3.247.183,- dengan nilai $\mathrm{R} / \mathrm{C}$ sebesar 1,48 dan 1,13 . Nilai $R / C$ yang lebih dari 1 menunjukan bahwa usahatani padi baik pada usahatani padi organik dengan padi anorganik layak untuk diusahakan.

Untuk melihat apapakah ada perbedaan pendapatan antara pendapatan padi organik dengan anorganik dilakukan pengujian uji beda. Berdasarkan hasil uji beda dengan menggunakan pengujian sampel Independent Samples $T$ Test diperoleh nilai nilai Sig. (2-tailed) sebesar 0,028 . Nilai ini $<0,05$ menunjukkan bahwa ada perbedaan yang signifikan (nyata) antara pendapatan padi organik dengan anorganik. Hasil pengujian ini dapat dilihat pada Lampiran 1.

\section{Persepsi Anggota terhadap Peran Kelompok}

Identifikasi peran Kelompok Tani Ciloa terhadap anggota kelompok dalam membantu memecahkan masalah-masalah usahatani, kemudahan akses pasar, informasi, dan teknologi serta permodalan dapat dilihat pada Tabel 2. 
Tabel 2 Persepsi Petani terhadap Peran Kelembagaan Kelompok Tani Ciloa dan Subur Tani di Desa Limbangan Kecamatan Sukaraja, 2019



Sumber : Data primer diolah, 2019 
Berdasarkan data pada Tabel 2, terlihat bahwa pada petani organic, petani setuju bahwa kelompok tani dapat berperan dalam mengatasi konflik atau kendala yang terjadi dalam kelompok diselesaikan bersama secara kekeluargaan, selanjutnya peran kelompok tani diperspsikan dapat saling membantu dan tolong menolong apabila terdapat petani yang mengalami masalah dalam usahataninya, urutan ketiga dari persepsi petani adalah tiap anggota bebas mengungkapkan pendapat untuk membantu menyelesaikan masalah yang dihadapi kelompok atau saran demi kemajuan kelompok. Namun ternyata peran kelompokn tbelum dapat meningkatkan pendapatan petani setiap musim panen, kelompok belum dapatmemenuhi kebutuhan dalam mengakses modal dan kelompok juga belum bereperan dalam kemudahan mendapatkan bantuan dari Dinas Pertanian, Dinas Ketahan Pangan Kabupaten Sukabumi secara rutin.

Berbeda dengan Kelompok Tani Ciloa, pada Subur Tani anggota kelompok mempersepsikan kelompok dapat berperan dalam membantu dan tolong menolong apabila terdapat petani yang mengalami masalah dalam usahataninya, dapat menengahi konflik atau kendala yang terjadi dalam kelompok diselesaikan bersama secara kekeluargaan, dan tiap anggota bebas mengungkapkan pendapat untuk membantu menyelesaikan masalah yang dihadapi kelompok atau saran demi kemajuan kelompok. Yang menarik baik untuk Kelompok Tani maupun Ciloa, anggota mempersepsikan bahwa kelompok belum dapat berperan dalam meningkatkan pendapatan petani setiap musim panen dan juga belum berperan dalam memberikan kemudahan mendapat bantuan dari Dinas Pertanian, Dinas Ketahan Pangan Kabupaten Sukabumi secara rutin. Skor rata-rata untuk kedua kelompok bernilai 3,87 dan 3,8 menunjukkan bahwa persepsi anggota terhadap peran kelompok sudah baik.

\section{Biaya Transaksi Kelompok Tani Padi Organik dan Anorganik}

\section{Biaya Transaksi Kelompok Tani Ciloa \\ Biaya transaksi yang diperhitungkan dan dibandingkan dengan penerimaan kelompok hanya biaya tansaksi operasional yang dikeluarkan setiap tahunnya. Besarnya biaya transaksi yang dikeluarkan Kelompok Tani Ciloa dapat dilihat pada Tabel 3}

Tabel 3 Biaya Transaksi Kelompok Tani Ciloa di Desa Limbangan Kecamatan Sukaraja, 2019

\begin{tabular}{llrl}
\hline No & \multicolumn{1}{c}{ Jenis Biaya Transaksi } & Nilai (Rupiah) & \multicolumn{1}{c}{ Keterangan } \\
\hline & Biaya Operasional : & & \\
1. & Biaya Pelatihan/ Studi Banding & $3.000 .000,00$ & Biaya pelatihan, \\
2. & Biaya Sosialisasi/penyuluhan & $2.000 .000,00$ & sosialisasi, kumpul \\
3. & Biaya Kumpul Rutin & $600.000,00$ & rutin, musyawarah \\
4. & Biaya Musyawarah/ Pertemuan & $1.200 .000,00$ & dan perwatan mesin \\
& dengan Anggota Kelompok & & dikeluarkan setiap \\
5. & Biaya Perawatan Mesin Inventaris & $200.000,00$ & tahun \\
& Kelompok & & \\
\hline & Total Biaya Transaksi & $7.000 .000,00$ & \\
\hline
\end{tabular}

Berdasarkan data pada Tabel 3, biaya transaksi total yang dikeluarkan oleh Kelompok Tani Ciloa setiap tahun mencapai Rp7.000.000,00. Biaya ini selalu dikeluarkan setiap tahunnya dan berbeda dengan biaya membuat kontrak (akta notaris) yang hanya dikeluarkan sekali ketika awal pembentukan kelompok. 

Tabel 4 Penerimaan Kelompok Tani Ciloa di Desa Limbangan Kecamatan Sukaraja, 2019

\begin{tabular}{clrl}
\hline No & Sumber Penerimaan & Nilai (Rupiah) & \multicolumn{1}{c}{ Keterangan } \\
\hline 1. & Iuran Anggota & $1.920 .000,00$ & $\begin{array}{l}\text { Penerimaan kelompok dari } \\
\text { iuran anggota setiap tahun } \\
\text { 2. }\end{array}$ \\
$\begin{array}{l}\text { Penjualan Beras } \\
\text { Organik }\end{array}$ & $28.866 .000,00$ & $\begin{array}{l}\text { Penerimaan dari penjualan } \\
\text { beras organik yang } \\
\text { dikembangkan oleh } \\
\text { kelompok setiap tahun }\end{array}$ \\
\hline & Total Penerimaan & $30.786 .000,00$ & \\
\hline
\end{tabular}

Berdasarkan data pada Tabel 4, penerimaan Kelompok Tani Ciloa berasal dari iuran anggota dan usaha mandiri untuk menunjang kebutuhan kelompok. Iuran anggota dilakukan setiap bulan sebesar Rp2.000,00/bulan. Penerimaan kelompok dari penjualan beras organik sebesar Rp28.866.000,00. Biaya yang dikeluarkan oleh petani demi majunya kelompok tani memberikan dampak positif terhadap keterampilan petani itu sendiri dan pengembangan usahatani.
Data pada Tabel 5 menunjukkan rasio biaya transaksi terhadap penerimaan Kelompok Tani Ciloa. Jika dilihat dari tingkat efisiensi penerimaan yang dihitung berdasarkan rasio biaya transaksi terhadap penerimaan, petani padi organik memiliki tingkat efisiensi penerimaan 0,23 artinya bahwa dalam setiap Rp1000,00 penerimaan, petani mengeluarkan biaya transaksi sebesar Rp230.

Tabel 5 Rasio Biaya Transaksi-Penerimaan Kelompok Tani Ciloa di Desa Limbangan Kecamatan Sukaraja, 2019

\begin{tabular}{clr}
\hline No & \multicolumn{1}{c}{ Uraian } & \multicolumn{1}{c}{ Nilai (Rupiah) } \\
\hline 1. & Biaya Transaksi & $7.000 .000,00$ \\
2. & Penerimaan Kelompok & $30.786 .000,00$ \\
\hline & Rasio Biaya Transaksi-Penerimaan (TrC/R) & 0,23 \\
\hline
\end{tabular}

\section{Biaya Transaksi Kelompok Tani Subur} Tani

Biaya transaksi yang diperhitungkan dan dibandingkan dengan penerimaan kelompok hanya biaya tansaksi operasional yang dikeluarkan setiap tahunnya. Besarnya biaya transaksi Kelompok Tani Subur Tani dapat dilihat pada Tabel 6 .

Tabel 6 Biaya Transaksi Kelompok Tani Subur Tani di Desa Limbangan Kecamatan Sukaraja, 2019

\begin{tabular}{llrl}
\hline No & \multicolumn{1}{c}{ Jenis Biaya Transaksi } & Nilai (Rp) & \multicolumn{1}{c}{ Keterangan } \\
\hline & Biaya Operasional : & & \\
1. & Biaya Sosialisasi/penyuluhan & $1.000 .000,00$ & $\begin{array}{l}\text { Biaya pelatihan, } \\
\text { sosialisasi, kumpul rutin, } \\
\text { 2. Biaya Kumpul Rutin }\end{array}$ \\
3. $\begin{array}{l}\text { Biaya Musyawarah/ Pertemuan dengan } \\
\text { Anggota Kelompok }\end{array}$ & $1.200 .000,000,00$ & $\begin{array}{l}\text { musyarah dan perwatan } \\
\text { mesin dikeluarkan setiap }\end{array}$ \\
4. $\begin{array}{l}\text { Biaya Perawatan Mesin Inventaris } \\
\text { Kelompok }\end{array}$ & $200.000,00$ & \\
\hline & & & \\
\hline
\end{tabular}


Tabel 7 Penerimaan Kelompok Tani Subur Tani di Desa Limbangan Sukaraja, 2019

\begin{tabular}{llcl}
\hline No & Sumber Penerimaan & $\begin{array}{c}\text { Nilai } \\
\text { (Rupiah) }\end{array}$ & \multicolumn{1}{c}{ Keterangan } \\
\hline 1. & Iuran Anggota & $2.880 .000,00$ & $\begin{array}{l}\text { Penerimaan kelompok dari } \\
\text { iuran anggota setiap tahun } \\
\text { Penerimaan sewa traktor } \\
\text { 2. }\end{array}$ Sewa Traktor \\
Sotal Penerimaan & $3.000 .000,00$ \\
\hline
\end{tabular}

Berdasarkan Tabel 7, penerimaan Kelompok Tani Subur Tani berasal dari iuran anggota dan usaha mandiri untuk menunjang kebutuhan kelompok. Iuran anggota dilakukan setiap bulan sebesar Rp2.000,-/bulan. Penerimaan kelompok juga berasal dari penyewaan traktor sebesar Rp3.000.000,-/tahun.

Tabel 8 Rasio Biaya Transaksi-Penerimaan Kelompok Tani Subur Tani di Desa Limbangan Kecamatan Sukaraja, 2019

\begin{tabular}{clr}
\hline No & \multicolumn{1}{c}{ Uraian } & \multicolumn{1}{c}{ Nilai (Rupiah) } \\
\hline 1. & Biaya Transaksi & $3.000 .000,00$ \\
2. & Penerimaan Kelompok & $5.880 .000,00$ \\
\hline & Rasio Biaya Transaksi-Penerimaan (TrC/R) & 0,51 \\
\hline
\end{tabular}

\begin{abstract}
Tabel 8 memperlihatkan nilai rasio biaya transaksi terhadap penerimaan Kelompok Tani Subur Tani. Nilai efisiensi penerimaan petani padi anorganik memiliki tingkat efisiensi penerimaan 0,51 artinya bahwa dalam setiap Rp1000,00 penerimaan, petani mengeluarkan biaya transaksi sebesar Rp510.
\end{abstract}

\section{KESIMPULAN DAN IMPLIKASI KEBIJAKAN}

\section{Kesimpulan}

Berdasarkan hasil penelitian dapat disimpulkan :

1. Pendapatan usahatani padi organik lebih besar dibandingkan dengan padi anorganik. Berdasarkan nilai $\mathrm{R} / \mathrm{C}$ untuk kedua usahatani layak untuk dijalankan (R/C 1,48 dan 1,13).

2. Persepsi petani baik padi organik maupun anorganik terhadap peran kelembagaan kelompok tani dinilai sudah baik terutama dalam hal menyelesaikan konflik yang terjadi antar kelompok yang dapat diselesaikan secara kekeluargaan, interaksi antar anggota kelompok tani yang saling membantu ketika petani lain membutuhkan bantuan, dan bebas mengeluarkan pendapat dalam kelompok. Namun menurut persepsi petani, kelompok belum dapat berperan untuk dapat meningkatkan pendapatan setiap musim, dan akses ke Dinas Pertanian dalam menerima bantuan masih relative sulit.

3. Rasio biaya transaksi terhadap penerimaan Kelompok Tani Ciloa dan Subur Tani sebesar 0,23 dan 0,51. Hal ini menunjukkan bahwa kelembagaan Kelompok Tani Ciloa (untuk padi organic) relatif lebih efisien karena mengeluarkan biaya transaksi yang lebih kecil dibandingkan Kelompok Tani untuk padi anorganik.

\section{Implikasi Kebijakan}

1. Berdasarkan perhitungan, pendapatan usahatani padi organic lebih tinggi, maka disarankan untuk meningkatkan pendapatan, petani padi anorganik dapat mengurangi biaya terutama biaya pupuk kimia sebagai komponen biaya yang paling tinggi 
2. Bagi petani padi organik maupun anorganik, peran kelompok tani sangatlah diperlukan dan kinerja kelompok taninya perlu ditingkatkan terutama membantu petani dalam meningkatkan pendapatannya, dan memberi kemudahan terhadap akses pasar dan informasi dalam

\section{DAFTAR PUSTAKA}

Aminah, Mimin, Musa Hubeis,

Widiatmaka, Hari Wijayanto. 2018.

Hambatan Partisipasi Petani dalam

Pengembangan Padi Organik di

Kabupaten Tasikmalaya (Obstacles Of

Farmers Participation In Organic Rice

Development In Tasikmalaya

District). Jurnal Pengelolaan

Sumberdaya Alam dan Lingkungan

Vol. 8 No. 3 (Desember 2018): 330338

Astuty, Ismi Dinar. 2017. Analisis Kelembagaan Pertanian Mina Padi dan Padi Konvensional di Desa Margoluwih Kabupaten Sleman Yogyakarta. Skripsi. Departemen Ekonomi Sumberdaya dan Lingkungan. Fakultas Ekonomi dan Manajemen IPB: Bogor.

Badan Pusat Statistik. 2019. Perkembangan Luas Panen, Produktivitas dan Produksi Padi di Provinsi Jawa Barat Tahun 20142018.www.bps.go.id. Diakses Pada 30 Juli 2019.

Badan Standarisasi Nasional. 2015. Standar Pangan Organik. http://sisni.bsn.go.id/index.php? /sni_main/sni/_detail_sni/10438. diakses pada 31 Juli 2019 pukul 21.25 mendapatkan bantuan dari Dinas Pertanian Tanaman Pangan

3. Kelompok tani Subur Tani sebaiknya dapat mencari alternatif untuk meningkatkan penerimaan bagi kelompok taninya dan mengurangi biaya transaksi supaya kelembagaan kelompok tani lebih efisien.

Direktorat Jendral Tanaman Pangan. 2016 Petunjuk Teknis Pengembangan Desa Pertanian Organik Padi Tahun 2016. Kementrian Pertanian. Jakarta

Nuraini, Candra, Dwidjono Hadi Darwanto, Masyhuri, Jamhari.2016. Model Kelembagaan padaAgribisnis Padi Organik KabupatenTasikmalaya. Jurnal Agraris Vol.2 No.1 Januari 2016

Peraturan Menteri Pertanian Republik Indonesia Nomor 67/Permentan/Sm.050/12/2016. 2016. Pembinaan Kelembagaan Petani. Jakarta . Kementrian Pertanian

Pusdatin. 2016. Outlook Komoditas Pertanian Tanaman Sub Sektor Pangan Padi. Pusat data dan Sistem Informasi Pertanian Kementerian Pertanian. Jakarta.

Shinta, A. 2011. Ilmu Usahatani. Universitas Brawijaya Press

Soekartawi. 2006. Analisis Usahatani. UI Press. Jakarta.

Suratiyah. 2009. Ilmu Usahatani. Jakarta(ID): Penebar Swadaya.

Yustika AE. 2012. Ekonomi Kelembagaan Paradigma, Teori, dan Kebijakan. Jakarta(ID): Erlangga 
Lampiran 1. Hasil Perhitungan Uji T ( Idependent Simple T Test) Menggunakan SPSS 22

\begin{tabular}{|r|r|r|c|r|c|}
\hline & Responden & $\mathrm{N}$ & Mean & Std. Deviation & $\begin{array}{c}\text { Std. Error } \\
\text { Mean }\end{array}$ \\
\hline Pendapatan & 1,00 & 20 & 14635805,200 & 5333023,6495 & 1192500,3406 \\
& & 0 & 3 & 0 \\
& 2,00 & 30 & 27123161,700 & 1720844,6777 & 314181,81600 \\
\hline
\end{tabular}

\begin{tabular}{|c|c|c|c|c|c|c|c|c|c|c|}
\hline \multicolumn{11}{|c|}{ Independent Samples Test } \\
\hline & & $\begin{array}{r}\text { Lev } \\
\text { Tes } \\
\text { Equa } \\
\text { Vari } \\
\end{array}$ & $\begin{array}{l}\text { ne's } \\
\text { for } \\
\text { ity of } \\
\text { nces }\end{array}$ & \multicolumn{7}{|c|}{ t-test for Equality of Means } \\
\hline & & \multirow[b]{2}{*}{$\mathrm{F}$} & \multirow[b]{2}{*}{ Sig. } & \multirow[b]{2}{*}{$\mathrm{t}$} & \multirow[b]{2}{*}{$\mathrm{df}$} & \multirow{2}{*}{$\begin{array}{l}\text { Sig. } \\
(2- \\
\text { tailed })\end{array}$} & \multirow{2}{*}{$\begin{array}{c}\text { Mean } \\
\text { Difference }\end{array}$} & \multirow[b]{2}{*}{ Std. Error Difference } & \multicolumn{2}{|c|}{$\begin{array}{l}\text { 95\% Confidence Interval of the } \\
\text { Difference }\end{array}$} \\
\hline & & & & & & & & & Lower & Upper \\
\hline Pendapatan & $\begin{array}{l}\text { Equal } \\
\text { variances } \\
\text { assumed } \\
\text { Equal } \\
\text { variances } \\
\text { not } \\
\text { assumed }\end{array}$ & 5,151 & ,028 & $\begin{array}{r}11,976 \\
- \\
10,126\end{array}$ & 21,661 & $\begin{array}{l}, 000 \\
, 000\end{array}$ & $\begin{array}{r}12487356,50000 \\
12487356,50000\end{array}$ & $\begin{array}{l}1042715,77955 \\
1233193,93277\end{array}$ & $\begin{array}{r}14583877,08869 \\
15047167,59823\end{array}$ & $\begin{array}{r}-10390835,91131 \\
-9927545,40177\end{array}$ \\
\hline
\end{tabular}

